\title{
How Organizational Climate Mediates Employee Innovative Work Behavior among Food Manufacturing Industries in COVID-19 Pandemic: Implications to Business Economics and Management
}

\author{
CHI HAU TAN ${ }^{1}$, HARSANDALDEEP KAUR ${ }^{2}$, A. APSARA SALETH MARY ${ }^{3}$, \\ MICHAEL BHOBET BALUYOT ${ }^{4}$, MA. DINA D. JIMENEZ ${ }^{5}$, RANDY JOY M. VENTAYEN ${ }^{6}$, \\ JUPETH TORIANO PENTANG ${ }^{7}$ \\ ${ }^{1}$ UNIVERSITI TUNKU ABDUL RAHMAN, MALAYSIA. E-mail' tanchih@utar.edu.my \\ ${ }^{2}$ GURU NANAK DEV UNIVERSITY, INDIA. E-mail: harsandal.usfs@gndu.ac.in \\ ${ }^{3}$ MADURAI KAMARAJ UNIVERSITY, INDIA. \\ 4,5TECHNOLOGICAL UNIVERSITY OF THE PHILIPPINES, PHILIPPINES. \\ ${ }^{6}$ PANGASINAN STATE UNIVERSITY, PHILIPPINES. \\ ${ }^{7}$ WESTERN PHILIPPINES UNIVERSITY, PHILIPPINES.
}

\begin{abstract}
In this context, the study explored the relationship between organizational climate and employee innovative work behaviour among food manufacturing industries in Malaysia. The study is a descriptive correlational survey research design where data is sourced out from a total of randomly sampled 260 employees. Results revealed that a favourable organizational climate on innovation, proactivity, and risk-taking is prevailing among the companies. A very high level of innovative work behaviour is emanating among the employees on idea exploration, generation, championing, and implementation. Test of differences showed that employee gender, position, unit, and years of service spelt significant differences in the perception of the employees on organizational climate and innovative work behaviour. A meaningful relationship surfaced between organizational climate and employee innovative work behaviour, suggesting that for food manufacturing industries to sustain innovative and competitive advantages, there is a need to promote a nurturing and encouraging entrepreneurial organizational climate. Finally, a congruency among the domains of organizational climate and employee innovative work behaviour emerged. It suggests that when higher positive organizational climate surfaces, the more likely the employee's manifest innovation work behaviour. This study addressed the gap by providing organizational climate and employee innovative work behaviour among food manufacturing industries in Malaysia.
\end{abstract}

Keywords: Organizational climate; Employee innovative work behaviour; Food manufacturing industries; Innovation.

JEL Classification: L2, L66, M14

Received: June 23, 2021

Accepted: September 16, 2021 


\title{
Cómo Influye el Clima Organizativo en el Comportamiento Laboral Innovador de los Empleados de las Industrias Alimentarias en la Pandemia de COVID-19: Implicaciones para la Economía y la Gestión Empresarial
}

\author{
CHI HAU TAN ${ }^{1}$, HARSANDALDEEP KAUR ${ }^{2}$, A. APSARA SALETH MARY ${ }^{3}$, \\ MICHAEL BHOBET BALUYOT ${ }^{4}$, MA. DINA D. JIMENEZ ${ }^{5}$, RANDY JOY M. VENTAYEN ${ }^{6}$, \\ JUPETH TORIANO PENTANG ${ }^{7}$ \\ ${ }^{1}$ UNIVERSITI TUNKU ABDUL RAHMAN, MALAYSIA. E-mail tanchih@utar.edu.my \\ 2GURU NANAK DEV UNIVERSITY, INDIA. E-mail: harsandal.usfs@gndu.ac.in \\ ${ }^{3}$ MADURAI KAMARAJ UNIVERSITY, INDIA. \\ 4,5TECHNOLOGICAL UNIVERSITY OF THE PHILIPPINES, PHILIPPINES. \\ ${ }^{6}$ PANGASINAN STATE UNIVERSITY, PHILIPPINES. \\ ${ }^{7}$ WESTERN PHILIPPINES UNIVERSITY, PHILIPPINES.
}

\begin{abstract}
RESUMEN
En este contexto, el estudio explora la relación entre el clima organizativo y el comportamiento laboral innovador de los empleados de las industrias alimentarias de Malasia. Se trata de un estudio descriptivo y correlacional en el que los datos proceden de una muestra aleatoria de 260 empleados. Los resultados revelaron que en las empresas prevalece un clima organizativo favorable a la innovación, la proactividad y la asunción de riesgos. Los empleados muestran un nivel muy alto de comportamiento innovador en la exploración, generación, defensa y aplicación de ideas. La prueba de las diferencias demostró que el género, el cargo, la unidad y los años de servicio de los empleados suponían diferencias significativas en la percepción de los empleados sobre el clima organizativo y el comportamiento laboral innovador. Se observó una relación significativa entre el clima organizativo y el comportamiento laboral innovador de los empleados, lo que sugiere que, para que las industrias de fabricación de alimentos mantengan ventajas innovadoras y competitivas, es necesario promover un clima organizativo que fomente el espíritu empresarial. Por último, surgió una congruencia entre los ámbitos del clima organizativo y el comportamiento laboral innovador de los empleados. Sugiere que cuanto más positivo sea el clima organizativo, más probable será que el empleado manifieste un comportamiento laboral innovador. Este estudio aborda el vacío existente al proporcionar el clima organizacional y el comportamiento laboral innovador de los empleados entre las industrias de fabricación de alimentos en Malasia.
\end{abstract}

Palabras clave: Clima organizativo; Comportamiento laboral innovador de los empleados; Industrias alimentarias; Innovación.

Clasificación JEL: L2, L66, M14

Recibido: 23 de Junio de 2021

Aceptado: 16 de Septiembre de 2021 


\section{Introduction}

The coronavirus disease of 2019 (COVID-19) has had a significant effect on the economy and public health. The COVID-19 epidemic has put a lot of strain on those still working since they have had to become used to working remotely quickly. Similarly, colleges have had to make a fast shift from the "work office" to the "home office." Although they are "open for business" on an institutional level, proof of their capacity to successfully execute their fundamental duties in an online environment is only just surfacing now. Identifying the most critical influences on academics' work may help us better understand when a "new normal" has been established and when lockdown will be necessary. Understanding the variables that hinder or encourage the effective implementation of online distribution and how to enable better academic research can help the sector be more resilient and productive.

Progress through innovation is the byword of business firms in the present-day knowledge-based economy. Innovation is responsible for success and competitiveness in many industries of the world. As a result, topics regarding the factors of business organizations that influence change received extensive attention and discussion. The call for reorienting entrepreneurial managers on intensive investment to organizational climate and human resource creativity is a relevant research inquiry (Saraswati \& Putra, 2020). Rapid technological development intensifies global competition. Production of novel ideas, processes, and systems are given a central place among companies to withstand the challenge. The model of interactive organizational creativity (Woodman, Sawyer \& Griffin, 1993) postulates that individuals and organizations have an interactive effect on innovative employee behaviour, which explains that creative climate is a vital context variable to promote employee innovative work behaviour. One of the factors which consistently emerged as a propeller of employee innovation is the organizational climate. The dearth of literature regarding organizational climate and employee innovative work behaviour in the context of food manufacturing industries is emphasized. This paper offers a new and fresh perspective for the study of innovative human behaviour in the organizational context, considering that human resource is the most valuable element of business organizations. It presents relevant implications by deepening the understanding of the creativity styles of Malaysian employees in food manufacturing industries as well as the promotion of favourable organizational climate which supports individuals to thrive in the organization by initiating food products innovations.

\subsection{Organizational climate}

Organizational climate is a collective and collegial sharing of perceptions regarding the attributes of the work environment of an organization. These attributes pertain to the systems, procedures, practices, and rewarded behaviours which the people of the organization share to establish a climate that is innovative, proactive, and risk-taking (Kang, Matusik, Kim \& Phillips, 2016). In this context, organizational climate is the psychological working environment of the people, which influences their work behaviour leading to satisfaction or dissatisfaction (Puspitawati \& Atmaja, 2019; Pati, 2019). A favourable organizational climate is a powerful determinant of job satisfaction and motivation, which is directly related to the effectiveness, efficiency, and productivity of the employees (Norton, Zacher \& Ashkanasy, 2015; Nencini, Romaioili \& Meneghini, 2016; Banerjee, Gupta \& Bates, 2017). Although studies have shown that different types of organizational climate exist and co-exist in any organization (MacCormick \& Parker, 2010; Wallace et al., 2016), employees may construct different types of psychological construct towards it. Hence, the employees' readiness to implement and initiate innovations is dictated by their perceptions in a given organizational situation where a supportive organizational climate will make them feel more productive. Research about organizational climate and employee innovative work behaviour in the context of food manufacturing industries is limited. 


\subsection{Employee innovative work behaviour}

Another significant variable of the study is the employee innovative work behaviour which is equally important to organizational climate. The creative practice of employees in an organization has been viewed as one of the essential critical factors of sustained competitiveness (Montani, Courcy \& Vandenberghe, 2017; Bani-Melhem, Zeffane \& Albaity, 2018; Lin \& Lin, 2019; Mehmood, Jian, Waheed, Younas \& Khan, 2019). It refers to the ability of the people in business organizations to initiate idea exploration, idea generation, idea championing, and idea implementation (de Jong \& den Hartog, 2010). Several studies have discussed that the employees are the forerunners of innovation in many organizations. Statistics confirmed that employees are responsible for approximately $80 \%$ of new ideas and discoveries for utilization and commercialization by business industries (Getz \& Robinson, 2003; Jeanes, 2006; Imran, Saeed, Anis-Ul-Haq \& Fatima, 2010). It presents that the employees are the most valuable resource of any organization. Innovation scholars have also pointed out that innovation is influenced by many driving factors related to the company-specific features (Malerba, 2007), including organizational climate and support. The innovative work behaviour of employees is, therefore, fundamental to understand for a business to thrive. Looking at their perceptions and addressing their obstacles and difficulties towards innovation will allow them to contribute change to the organizations. In the context of this study, there is a dearth of literature exploring innovative employee behaviour in food manufacturing industries.

\subsection{Context and research gaps}

Malaysia is one of the largest, most innovative economies of the world through its patents, utility models, trademarks, and industrial design filed and approved. The food industry in Malaysia has a long historical trend and gained rapid development after the industrial revolution. Among the core, major industries in include manufacturing, warehousing, distribution, and retailing (Ju, 2012). In this study, the food manufacturing industries in Malaysia are being highlighted to investigate their prevailing organizational climate and employee innovative work behaviours. It hopes to provide important soft human features of these food industries which will contribute to their innovation, particularly on product innovation. Joe, Bessant, and Pavitt (2005) put into context the definition of innovation as a process of turning opportunity into new ideas and translate these into widely practice, system, process, and product. The food companies are pursuing product and process innovations to gain a competitive edge in the market.

Several works of literature regarding various aspects of food industries have been conducted. For instance, on product innovation (Ju, 2012; Ming, Yang \& Zhen, 2016; Jin, Zhu \& Xu, 2017), on food safety and security (Lu et al., 2015; Kang et al., 2017; Miao et al., 2017). Consequently, studies regarding organizational climate and innovation are also evidential in many pieces of literature (Li, Zhao \& Begley, 2015; Wang \& Chang, 2017; Vong, Ngan \& Lo, 2018; Hughes, Lee, Tian, Newman \& Legood, 2018; Liu, Chow, Zhang \& Huang, 2019). However, studies focusing on innovation activities of food processing firms in Malaysia have not yet gained much attention in the existing literature, particularly on their organizational climate and employee innovative work behaviour. Innovation, which plays a significant role in the national economy, is a determinant of competitive success. This paper focuses on the exploration of the prevailing organizational climate and employee innovative work behaviour among food manufacturing industries.

\section{Objectives of the study}

This study explored the relationship between organizational climate and employee innovative work behaviour in the context of Malaysian food manufacturing industries. It specifically sought to: (1) describe the existing organizational climate of Malaysian food manufacturing industries; (2) determine the prevailing innovative work behaviours of the employees; (3) ascertain the differences in the innovative work behaviours of the employees when category grouped into their personal profile 
variables; (4) ascertain the congruent factors of organizational climate and employees' innovative work behaviour.

\subsection{Hypotheses}

This study tested the following hypotheses in null form:

1. There is no significant difference in the perceptions of the employees on the organizational climate when grouped according to the select profile variables (gender, position, unit, and years of service).

2. There is no significant difference in the employees' innovative work behaviour when grouped according to the select profile variables (gender, position, unit, and years of service).

3. There is no relationship between the organizational climate and employees' innovative work behaviour domains.

\section{Methodology}

\subsection{Research design, sampling, and procedure}

The study employed a descriptive correlational survey research design examining the relationship between organizational climate and employee innovative work behaviour in the context of Malaysian food manufacturing industries. Data were sourced out from 28 companies with a total population of 800 employees. The multi-stage process of sampling is used. For selecting the companies, the criteria inclusion of choosing the companies was based on the complete list of registered food manufacturing industries with at least more than ten years of operation which are exposed to a competitive market with at least 30 registered patents and utility models. From the population of 800 employees, a total of 260 employees (immediate supervisors and employees) were sampled and calculated using the Raosoft sampling calculator set with a $5 \%$ margin of error and $95 \%$ level of confidence, and $50 \%$ distribution rate. The systematic sampling method was employed to get the names of participants the technique involved in selecting every kth element of the population with a random start number of eight. Anchored on the ethical research consideration, personal information and details given by the participants were confidentially treated. Before the selection and identification and selection of participants, a written request was sent and approved by the authorities. The data privacy agreement form was also filled out by the respondents. Mailing of letters to the identified companies requesting the participation of the respondents was conducted. The human resource officers approved requests with personal visits undertaken by the researcher. One hundred percent retrieval rate was obtained. To pave a clearer understanding on the personal characteristics of the respondents, their profile variables were described by answering the personal information sheet consisting only of their gender, position, unit, and years of service. These variables can be considered as factors of organizational climate and innovative work behaviour. The anonymity of the respondents was observed with the use of coding. Selected personal profile variables were identified, which will provide important implications to the research inquires of the present study. Previous studies highlights the importance of using descriptive correlational research in knowledge generation ( Ahorro, et al, 2021, Charernnit, et al, 2021, De Souza, et al, 2021, Lopez, et al, 2021, Magulod Jr, 2017, , Magulod Jr, 2019, Magulod, et al, 2021, Magulod, et al, 2020, Nuncio, et al, 2020).

Table 1 presents the frequency and percentage distribution of the respondents of the study. The majority of the respondents are female, with $61.54 \%$ over the male respondents with $38.46 \%$. As to position, $\mathbf{7 1 . 1 5} \%$ are employees, while $28.85 \%$ are supervisors. For departmental units of the respondents, $26.54 \%$ is accounted to those in the food innovation unit, $23.08 \%$ from marketing and sales unit, $21.15 \%$ is accounted to those from IT and data management unit, $19.23 \%$ from processing unit, and the least $10 \%$ from packaging unit. The data also shows that the majority, or $32.31 \%$, of the respondents, have 11-15 years of service in the company. The data in Table 1 categorically suggests that the major contributors of the study are female, rank, and file employees working at the different 
technology and innovation-oriented units, and the majority of them are experienced employees of the food manufacturing industries in Malaysia.

Table 1 Profile variables

\begin{tabular}{|c|c|c|c|}
\hline $\begin{array}{c}\text { Profile } \\
\text { Variables }\end{array}$ & Categories & $\begin{array}{c}\text { Frequency } \\
\text { Distribution } \mathbf{( n = 2 6 0 )}\end{array}$ & $\begin{array}{c}\text { Percentage } \\
\text { Distribution }\end{array}$ \\
\hline \multirow{3}{*}{ Gender } & Male & 100 & 38.46 \\
\cline { 2 - 4 } & Female & 160 & 61.54 \\
\hline \multirow{3}{*}{ Position } & Supervisor & 75 & 28.85 \\
\cline { 2 - 4 } & Employee & 185 & 71.15 \\
\hline \multirow{3}{*}{ Unit } & Food Innovation Unit & 69 & 26.54 \\
\cline { 2 - 4 } & IT and Data Management Unit & 55 & 21.15 \\
\cline { 2 - 4 } & Marketing and Sales Unit & 60 & 23.08 \\
\cline { 2 - 4 } & Processing Unit & 50 & 19.23 \\
\hline \multirow{3}{*}{$\begin{array}{c}\text { Years of } \\
\text { Service }\end{array}$} & Packaging Unit & 26 & 10.00 \\
\cline { 2 - 4 } & Below 5 years & 18 & 6.92 \\
\cline { 2 - 4 } & $6-10$ years & 36 & 32.31 \\
\cline { 2 - 4 } & $11-15$ years & 84 & 25.38 \\
\cline { 2 - 4 } & $16-20$ years & 66 & 13.08 \\
\hline
\end{tabular}

\subsection{Research Measures}

\subsubsection{The measure of organizational climate}

The organizational climate of food manufacturing industries of Malaysia was measured adopted from the organizational climate study of Kang et al. (2016) was used. The adopted items from previous organizational climate studies (Covin \& Slevin, 1989; Scott \& Bruce, 1994; Baer \& Frese, 2003; Patterson et al., 2005; Hughes \& Morgan, 2007). The instrument consisted of 18 items clustered into three important factors of organizational climate, namely innovative climate $(\alpha=0.71)$, proactive climate $(\alpha=0.83)$, and risk-taking climate $(\alpha=0.78)$. The instrument has six items in each factor with a 5-point Likert scale having the following scale ranges: strongly agree to strongly disagree with one as the lowest and five as the highest.

\subsubsection{The measure of employee innovative work behaviour}

Employees' innovative work behaviour is an essential concern for emerging and developed organizations around the world. The measure of innovative work behaviour of this study utilized the questionnaire developed by de Jong and den Hartog (2010), consisting of four critical dimensions, namely idea exploration, idea generation, idea championing, and idea implementation. The items in the instruments were sourced out from previous reliable studies (Scott \& Bruce, 1994; Janssen, 2000; Kleysen \& Street, 2001). The answered tool has a 5-point Likert scale with the following scale ranges: strongly agree to strongly disagree with one as the lowest and five as the highest. Responses were properly tabulated and subjected to an appropriate statistical test.

\subsubsection{Measures of analysis}

The data gathered came from survey design, where data was sourced from the supervisors and employees. Frequency and percentages were also used to describe the personal profile variables of the respondents. To analyze both the organizational climate and employee innovative work behaviour, the following descriptive statistics such as mean and standard deviation (SD) were used with the adopted interpretations and scale ranges: Strongly Agree/ Very High ${ }^{\mathrm{a}}$ (4.20-5.00); Agree/ High $^{\mathrm{b}}$ (3.404.19); Undecided/ Moderate ${ }^{c}$ (2.60-3.39); Disagree/ Low ${ }^{d}$ (1.80-2.59); Strongly Disagree/ Very Low ${ }^{e}$ 
(1.00-1.79). To ascertain the differences in the organizational climate and employee innovative work behaviour, a mean test of variations such as independent sample t-test, ANOVA, and post hoc-Tukey test were used. Considering that this study investigated the relationship between the factors of organizational climate and employee innovative work behaviour, the Pearson correlation coefficient was used to test the relationship.

\section{Results and Discussion}

\subsection{Organizational climate of food manufacturing industries}

The first specific question provided pictures of the current organizational climate among Malaysian food manufacturing industries. It captured the shared collective perceptions and retrospections of the employees on the attributes of the firms transcending from the positive or negative practices, procedures, and systems. This part of the study argues that the organizational climate among Malaysian food manufacturing industries plays a significant factor in motivating employees to achieve innovation and productivity. Table 2 reports the prevailing organizational climate among the food manufacturing industries of Malaysia. The result showed that both supervisors and employees generally agreed that they have a high level of organizational climate. It suggests that the employees highly share a positive organizational climate. In their context, the distinctive feature of the food industry highlights collaboration, cooperation, and effective communication with its crucial role in product innovation. Organizational climates are an important platform in modifying and intensifying creativity and innovation in workplaces (Khalili, 2016; Sethibe \& Steyn, 2016; Shanker, Bhanugopan, van der Heijden \& Farrell, 2017).

Table 2 Organizational climate

\begin{tabular}{|c|c|c|c|c|c|}
\hline $\begin{array}{c}\text { Domains of Organization } \\
\text { Climate }\end{array}$ & $\begin{array}{c}\text { Mean } \\
(\mathbf{n = 2 6 0 )}\end{array}$ & Median & SD & Interpretation & $\begin{array}{c}\text { Level } \\
\text { Description }\end{array}$ \\
\hline Innovative Climate & 3.89 & 4.00 & 1.08 & Agree & High \\
\hline Proactive Climate & 4.03 & 4.00 & 1.04 & Agree & High \\
\hline Risk-taking Climate & 3.85 & 4.00 & 1.04 & Agree & High \\
\hline Grand Mean & $\mathbf{3 . 9 2}$ & & $\mathbf{0 . 6 2}$ & Agree & High \\
\hline
\end{tabular}

Note: Strongly Agree/ Very High ${ }^{\text {a }}$ (4.20-5.00); Agree/ High $^{\text {b }}$ (3.40-4.19); Undecided/ Moderate ${ }^{\mathrm{c}}$ (2.60-3.39); Disagree/ Low ${ }^{\mathrm{d}}$ (1.80-2.59); Strongly Disagree/ Very Low ${ }^{\mathrm{e}}(1.00-1.79)$

A closer look at the table, the highest mean of $4.03(\mathrm{SD}=1.04)$ was obtained by proactive organizational climate domain implying that the companies have a high level of organizational climate which respondents agreed that they established a culture to initiate innovation and come up with practical actions to respond to the competitive business world, particularly on food product innovation. It infers that the companies provide opportunities to the employees to search for solutions to emerging business-related problems immediately. One of the practices of the company to promote a proactive organizational climate is giving rewards to the employees who introduce new products and services. The proactive climate of companies is considered very important since proactive behaviours among employees have a competitive advantage that encourages them to seize and find business opportunities before competitors take the initiative (Kang et al., 2016). Previous studies also confirmed that proactive climate in an organization is essential in pursuing and promoting innovation because it encourages personal initiatives among the employees, making them proactive to handle changes and unexpected issues in the workplace, which positively influenced organizational productivity (Fay, Lührmann \& Kohl, 2004; Spitzmuller, Sin, Howe \& Fatimah, 2015; Hong, Liao, Raub \& Han, 2016).

Correspondingly, the employees agreed that they have a high level of innovative climate, which was rated with a mean of $3.89(S D=1.08)$. It means that the companies have systems and mechanisms to support and recognize the achievement and outputs of the employees on food research and development and technological innovation. Hence, employees are being motivated to continually adapt to changes as they are also encouraged to develop new ideas and food product innovations. Among the practices the companies are doing is to recognize innovative employees during meetings 
and conferences, and they were given monetary incentives. The innovative work behaviour of employees is directly linked to organizational productivity. It shows that organizations with a strong climate of innovation emphasize the development of novel ideas (Kang, Solomon \& Choi, 2015; Shanker et al., 2017; Li, Bhutto, Nasiri, Shaikh \& Samo, 2018).

Finally, a high level of risk-taking climate is practised by the companies as inferred from the mean of 3.85 ( $\mathrm{SD}=1.04$ ), showing they can project calculated risks to every potential opportunity they may venture. Hence, employees are empowered to explore possibilities for companies. Scholars noted that a risks-taking climate among organizations explains innovative performance (García-Granero, Llopis, Fernández-Mesa \& Alegre, 2015; Iddris, Awuah \& Gebrekidans, 2016). It refers to how the people in the organizations collectively shared perceptions on tolerance and uncertainty since it permits them to make decisions by innovative suggestions. Digesting the result on this portion of the study showed that the food manufacturing industries of Malaysian are facilitating a positive organizational climate on innovation, proactivity, and risk-taking. Hence, this finding offers a significant answer to the inquiry that for food industries to deal with the emerging problems and gain competitive advantage is to build a collective climate of support and prioritization to innovation and strategies in dealing with change.

\subsection{Employees' innovative work behaviour of food manufacturing industries}

The ability to presently innovate products, systems and services is critical to any business organization without innovative-value-oriented employees. Henceforth, an individual's action to deal with improvement and innovation is crucial for organizations. The result in Table 3 shows the employee's innovative work behaviour. A very high employee innovative practice is seen among the employees of participating food manufacturing industries in Malaysia, as indicated by the grand mean of 4.28 (SD=0.44). The result displays that positive favourable employee creativity and innovative work behaviour are shared among the employees of the organizations. Dong, Bartol, Zhang, and Li (2017) confirmed that at a group level, creativity is the development and process or the outcome of integration among innovative and useful ideas by a group of people in an organization. Hence, in the food industry manufacturing context, the innovation of food products, technology packaging, and marketing are essential steps to be undertaken to satisfy the diverse and changing needs of their customers.

Table 3 Employees innovative work behaviour

\begin{tabular}{|c|c|c|c|c|c|}
\hline $\begin{array}{c}\text { Domains of Employee } \\
\text { Innovative Work Behaviour }\end{array}$ & $\begin{array}{c}\text { Mean } \\
(\mathbf{n = 2 6 0 )}\end{array}$ & Median & SD & Interpretation & Level Description \\
\hline Idea Generation & 4.24 & 4.00 & 0.82 & Strongly Agree & Very High \\
\hline Idea Exploration & 4.68 & 5.00 & 0.47 & Strongly Agree & Very High \\
\hline Idea Championing & 4.17 & 4.00 & 0.81 & Agree & High \\
\hline Idea Implementation & 4.05 & 4.00 & 0.99 & Agree & High \\
\hline Grand Mean & $\mathbf{4 . 2 8}$ & & $\mathbf{0 . 4 4}$ & Strongly Agree & Very High \\
\hline
\end{tabular}

Note: Strongly Agree/ Very High a (4.20-5.00); Agree/ High ${ }^{\text {b }}$ (3.40-4.19); Undecided/ Moderate ${ }^{\text {c }}$ (2.60-3.39); Disagree/ Low ${ }^{\text {d }}$ (1.80-2.59); Strongly Disagree/ Very Low ${ }^{\mathrm{e}}(1.00-1.79)$

Perusing the table, the employees have a very high level of idea generation with a mean of 4.24 $(S D=0.82)$. This domain ascertained the behaviour of the employees to relate themselves to develop new food products, systems, services, and processes from identified problems and gaps. The very high assessment of the employees to this domain shows strong adherence to their work value orientation is to generate ideas and knowledge to address problems in their companies. Ideas are essential keys to innovation in businesses. It refers to the process of constructing, creating, developing, and communicating concrete, representational, or abstract ideas. McAdam and McClelland (2002) noted that the most profitable products are those that will meet customers' needs. Hence, the generation of ideas and solutions to address them will profit the companies. Accordingly, Adams (2006) put it into the context that a working environment that is less bureaucratic facilitates a better flow of information to be more focused on idea generation. 
Relative to idea exploration, this assessed the ability of the employees to find ways in improving services, current products or try to think for alternative ways to improve their food products and processing. In this domain, the employees assessed themselves to have a very high level of idea exploration, evidenced by the mean of 4.68 ( $S D=0.47)$. The very high assessment shows that they manifest positive behaviour towards identifying problems and opportunities to gap the idea of "what is" and "what should be." Idea exploration is the starting point of innovation and invention. It is the discovery of an opportunity arising from a problem that will be the starting point of innovation. According to Basadur (2004), idea exploration is a process of innovation where current products and services are being improved.

As to idea championing, this domain refers to the products, systems, and processes being promoted by employees. In this domain, the employees assessed themselves to have a high level of idea championing, evidenced by the mean of $4.17(\mathrm{SD}=0.81)$. The high assessment shows that the respondents exhibit highly positive behaviour towards advocating or promoting ideas, systems, products, and processes they developed. These are employees who are capable of introducing change in the company in terms of the technologies they generate. They positively adhere that technology promotion is a process of introducing innovation and change by bringing it to apportion group of people, units, or organizations who will be the end-user of developed technology. Among the championing strategies, the employees' practice is technology dissemination and company policy recommendations. For Howell, Shea, and Higgins (2005), idea championing includes an advocacy campaign to express confidence regarding the success of innovation initiated.

Finally, the employee behaviour towards idea implementation involves the process of deploying, adapting, and commercializing developed or innovated technologies. In this domain, the employees assessed themselves to have highly favourable behaviour towards idea implementation as reflected with the mean of 4.05 ( $S D=0.99$ ). It implies that they have a positive drive to make their ideas become utilized properly or commercialized by the company. Kleysen and Street (2001) noted that idea implementation involves putting innovations as part of the routine work processes.

\subsection{The difference in the assessment on organizational climate when grouped into the respondents' profile variables}

To provide an answer to the research inquiry, the interplay of personal profile variables of Malaysian employees with their shared collective perceptions towards their organizations may have significant implications when grouped according to their profile variables. Table 4 shows significant differences in the assessment of the factors of organizational climate when grouped according to years of service and unit. Hence, the null hypothesis in this part of the study is rejected. This finding conveys that employees' years of service and unit spelled differences in organizational climate assessment. Looking intently at the result, the significant differences are seen on employees' years of services and unit where they belong are the variables defining differences in organizational climate, particularly on innovative, proactive, and risk-taking climate domains.

Table 4 Test of difference of organizational climate when grouped to the respondents' profile variables

\begin{tabular}{|c|c|c|c|}
\hline Control Variables & Innovative Climate & Proactive Climate & Risk-Taking Climate \\
\hline Gender & $0.618 \mathrm{~ns}$ & $0.831 \mathrm{~ns}$ & $0.163 \mathrm{~ns}$ \\
\hline Position & $0.180 \mathrm{~ns}$ & $0.890 \mathrm{~ns}$ & $0.262 \mathrm{~ns}$ \\
\hline Unit & $0.852 \mathrm{~ns}$ & $0.019^{*}$ & $0.047^{*}$ \\
\hline Years of Service & $0.006^{* *}$ & $0.293 \mathrm{~ns}$ & $0.023^{*}$ \\
\hline
\end{tabular}

Note: ${ }^{*} p<0.05 ;{ }^{* *} p<0.01 ;{ }^{* * *} p<0.00, n s=$ not significant

The difference showed on innovative climate $(p=0.006)$ and risk-taking climate $(p=0.023)$ when grouped into years of services of the employees is seen to those who have longer-tenure of service have the highest assessment on innovative perception compared to those who are relatively very young in the companies. This finding implies that those who have longer-tenured employees put higher acceptability to innovative works and risk-taking skills. Hence, they can see themselves as having a 
higher capacity to introduce innovation than those who are still very young in the service. $\mathrm{Ng}$ and Feldman (2013) concluded that older workers in organizations are innovative. Long-tenured employees have a high contribution to organizational innovation since position tenure is an influencing factor of innovation. Other researchers also confirmed that the finding of this study is that tenure is a moderating effect of ideation, invention, and innovation (Liu, Ge \& Peng, 2016; Woods, Mustafa, Anderson \& Sayer, 2018).

It is also seemingly important; employee unit spelt differences on proactive organizational climate $(p=0.019)$ and risk-taking climate $(p=0.047)$. This indicates that the food innovation unit, IT and data management unit, and marketing and sales unit put higher importance to proactive organizational climate because these are the forefront innovation-oriented units of companies with the primary tasks of carryout planning, forecasting of sales, and in-charge of product development and innovation initiatives making them explore opportunities and calculate risks. Hence, they are the primary thinkers of innovation and risks in food manufacturing companies. In order to gain competitive advantages with the rapidly growing and dynamic market, companies must be anticipative, adaptive, and agile to identify and evaluate alternate production and processing technology to enhance organizational productivity (Dengler, Schönmann, Lohmann \& Reinhart, 2017; Gitelman, Gavrilova, Kozhevnikov \& Starikov, 2019).

\subsection{The difference in the assessment on employee innovative work behaviour when grouped into the respondents' profile variables}

Table 4 presents the difference in the assessment of innovative employee work behaviour when grouped according to profile variables. The result showed a significant difference in innovative employee work behaviour when grouped according to gender, position, unit, and years of service. It suggests that personal profile variables spelt differences in the employees' innovative work behaviour.

Table 4 Test of difference employees innovative work behaviour when grouped into the respondents' profile variables

\begin{tabular}{|c|c|c|c|c|}
\hline Control Variables & Idea Exploration & Idea Generation & Idea Championing & Idea Implementation \\
\hline Gender & $0.008^{* *}$ & $0.222 \mathrm{~ns}$ & $0.024^{*}$ & $0.472 \mathrm{~ns}$ \\
\hline Position & $0.191 \mathrm{~ns}$ & $0.291 \mathrm{~ns}$ & $0.042^{*}$ & $0.116 \mathrm{~ns}$ \\
\hline Unit & $0.928 \mathrm{~ns}$ & $0.040^{*}$ & $0.803 \mathrm{~ns}$ & $0.248 \mathrm{~ns}$ \\
\hline Years of Service & $0.012^{*}$ & $0.029^{*}$ & $0.032^{*}$ & $0.113 \mathrm{~ns}$ \\
\hline
\end{tabular}

Note: ${ }^{*} p<0.05 ;{ }^{* *} p<0.01 ;{ }^{* * *} p<0.00, n s=$ not significant

An inspection of the table shows that gender spelt differences on the employee innovative work behaviour factors on idea exploration $(p=0.008)$ and idea championing $(p=0.024)$. The result favours women employees to have higher innovative work behaviour in these areas compared to their male counterparts. This result suggests that women employees manifest higher behaviour towards innovation than males in food manufacturing industries of Malaysia along with idea exploration and championing, which is attributed to the human nature of women as caring and conversant. Hence, the higher inclination on these factors. This finding concurs with Xie and Zhang (2015) traced the patterns of patents in China and concluded that there is a gender-ratio imbalance is increasing where femaledominated industries have exhibited higher innovations than in male-dominated industries. This finding was also confirmed by previous studies (Wei, Xie \& Zhang, 2017; Hu, Zhang \& Zhao, 2017; Rong, Wu \& Boeing, 2017).

As to position, the supervisors put more emphasis on idea championing $(p=0.042)$, implying that idea championing is a factor for them to become supervisors for them to communicate well innovative ideas and organizational direction to their subordinates. Hence, idea promotion highlights the process of exhibiting and possessing political and sales skills to convince a group of the quality of an idea, process, technology, or system. Černe, Kaše, and Škerlavaj (2016) described idea championing in a group level where someone is advocating for innovation and aims to generate positive behavioural support among its members. Previous literature also supports this finding that effective 
entrepreneurial leadership influences innovative work behaviour (Bagheri \& Akbari, 2018; Perry-Smith \& Mannucci, 2017; Berthoin Antal, Debucquet, G. \& Frémeaux, 2017).

Consequently, employees from the food innovation unit and IT and data management unit consistently put a higher importance on their positive behaviour towards idea generation $(p=0.040)$. It means that the role of food innovation and knowledge management units are equally important and crucial to sustaining their companies' competitive advantages. Martín-de Castro (2015) presents the rationale that knowledge is a valuable resource, as well as technological innovation are the critical sources of companies' competitive edge among knowledge-based and high-tech industries of the world. Also, a company's knowledge-based systems and practices create innovation which generates intrinsic value through financial or non-financial types (Natalicchio, Ardito, Savino \& Albino, 2017; De Silva, Howells \& Meyer, 2018).

Finally, those employees with higher years of service or those longer-tenured employees have higher behaviour towards idea exploration $(p=0.012)$, idea generation $(p=0.029)$, and idea championing $(p=0.032)$. It also supports the finding in Table 4 , showing that tenure has a moderating effect on ideation, invention, and innovation (Liu et al., 2016; Woods et al., 2018). Proving a clearer perspective, the role of long-tenured employees cannot be taken for granted by managers since these employees can contribute much to organizational productivity. Hence, this finding implies that career stages and tenure are also factors influencing innovative work behaviour.

\subsection{Relationship between organizational climate and employees innovative work behaviour}

This study hypothesized that in the Malaysian context, the positive or negative organizational climate could either strengthen or weakened employees' innovative work behaviour. The associations of the two significant dependent variables will help lessen the knowledge gap on the interactive outcome between organizational climate and innovative work behaviour of employees in food manufacturing industries. While a plethora of literature suggests that there is a positive mediating effect of organizational climate to employee innovative work behaviour (Wang, Kim \& Lee, 2016; Li, Mitchell \& Boyle, 2016; Dong et al, 2017; Kang et al., 2016; Hsu \& Chen, 2017; Berthoin Antal et al., 2017; Newman, Herman, Schwarz \& Nielsen, 2018; Wu \& Chen, 2018), there is still a dearth of studies looking at the specific factors of organizational climate and innovative work behaviour are correlated and congruent. In this study, relationships are explored. Table 5 reveals the relationship between the domains of organizational climate and the factors of innovative employee behaviour. The data showed that there is a significant relationship between organizational climates and innovative employee behaviour. Hence, then the null hypothesis of the study is rejected. It suggests that companies initiate innovation to promote a positive organizational climate (Jaiswal \& Dhar, 2015; Ghosh, 2015; NaranjoValencia, Jiménez-Jiménez \& Sanz-Valle, 2016; Shahzad, Xiu \& Shahbaz, 2017; Hsu \& Chen, 2017).

Table 5. Relationship of the factors

\begin{tabular}{|c|c|c|c|}
\hline Variables & Innovative Climate & Proactive Climate & Risk-taking Climate \\
\hline \multirow{2}{*}{ Idea Generation } & $\mathrm{r}=0.410$ & $\mathrm{r}=0.150$ & $\mathrm{r}=0.061$ \\
\cline { 2 - 4 } & $\mathrm{p}=0.043^{*}$ & $\mathrm{p}=0.015^{\star}$ & $\mathrm{p}=.325$ \\
\hline \multirow{2}{*}{ Idea Exploration } & $\mathrm{r}=0.025$ & $\mathrm{r}=0.110$ & $\mathrm{p}=0.256$ \\
\cline { 2 - 4 } & $\mathrm{p}=.683$ & $\mathrm{p}=.078$ & $\mathrm{r}=0.345$ \\
\hline \multirow{2}{*}{ Idea Championing } & $\mathrm{r}=0.034$ & $\mathrm{r}=0.006$ & $\mathrm{p}=0.041^{*}$ \\
\cline { 2 - 4 } & $\mathrm{p}=.587$ & $\mathrm{p}=.923$ & $\mathrm{r}=0.061$ \\
\hline \multirow{2}{*}{ Idea Implementation } & $\mathrm{r}=0.069$ & $\mathrm{r}=0.452$ & $\mathrm{p}=.327$ \\
\cline { 2 - 4 } & $\mathrm{p}=.266$ & $\mathrm{p}=0.023^{*}$ & \\
\hline
\end{tabular}

Note: ${ }^{*} p<0.05 ;{ }^{* *} p<0.01 ;{ }^{* * *} p<0.00$

As an interpretation and discussion of the positive relationship between the behaviour of employees towards idea, generation is associated with innovative $(p=0.043)$ and proactive $(p=0.015)$ organizational climate. It means that when employees are provided a positive organizational climate 
on innovation and proactivity, they better manifest idea generation behaviour. This further implies that in the context of food manufacturing industries in Malaysia, management needs to guarantee an organizational climate that nourishes, encourages, and enhances employee creativity and innovation. This finding construes with previous studies confirmed that when employees perceived greater support from the organizations, the most likely to practice and initiative on innovation (Shanker et al., 2017; Sauid, Kamarudzaman, Ebrahim, Mustakim \& Mokhtar, 2018; Hassan, Asif, Waqar, Khalid \& Abbas, 2018).

Similarly, a link between positive behaviour towards idea exploration $(p=0.035)$ and idea championing ( $p=0.041)$ between risk-taking climate has been found. This indicates that the risk-taking climate of the companies is associated with the employees' skill to find alternative ways in improving products, systems, and services, as well as their ability to promote their novel ideas. The willingness of the company to encourage risks significantly predicts employees' creativity on problem exploration. This result agrees with previous investigations (Dewett, 2006; Hammond, Neff, Farr, Schwall \& Zhao, 2011; Madjar, Greenberg \& Chen, 2011; Choudhury, 2012). Finally, behaviour towards idea implementation is correlated to proactive organizational climate $(p=0.023)$, implying that when employees are immersed in an organization with proactive measures to sustain their company's competitive edge, they are more likely to manifest eagerness to make their ideas become utilized properly or commercialized by the company. Several studies have shown that a proactive environment is linked to creativity (Orth \& Volmer, 2017; Li, Liu, Liu \& Wang, 2017; Petrou, Bakker \& Bezemer, 2019).

\section{Theoretical Implications}

The findings that emerged from the study provide significant theoretical implications on organizational climate and employee innovative work behaviour. Foremost, the dearth of literature regarding the two primary variables of the study, namely organizational climate and employee innovative work behaviour in the context of food manufacturing industries, is being emphasized where significant correlation is found. This paper offers a new and fresh perspective for the study of innovative human behaviour in an organizational context, considering that human resources in the most valuable element of business organizations. This, however, presents relevant implications by deepening the understanding of the creativity styles of Malaysian employees in food manufacturing industries as well as the promotion of favourable organizational climate which supports individuals to thrive in the organization by initiating food products innovations. Secondly, by providing a positive working environment to employees, they tend to develop a higher level of innovation supports the theory of creativity emphasized by Sternberg and Lubart (1991). The theory explains that six sources of human creativity are intellectual processes, knowledge, intellectual style, personality, motivation, and environmental context. Hence, creative performance results from a confluence of these elements where employees can build and foster innovation for organizational development. Thirdly, the results of the study also add to the body of knowledge regarding gender and tenure perceived creativity. The study found that women employees perceived themselves better on idea exploration and idea championing than males. Likewise, the role of employees having longer tenure in service cannot be underestimated but should be given importance since they see themselves innovative than their young counterparts. Hence, further students need to be conducted to validate the findings, which will strengthen the theoretical implications presented in this study.

\section{Practical Implications}

With regards to the practical implications of the study, Rowley, Baregheh, and Sambrook (2011) put into framework the types of innovation, namely paradigm innovation, product innovation, process innovation, and position innovation which call for human action to pursue to maintain a competitive advantage in the knowledge-driven economy of the world. This study is the pioneering work on the organizational climate and employee innovative work behaviour in the context of food manufacturing industries in Malaysia. Based on this, the researcher presents practical suggestions: First, for food 
manufacturing industries to maintain competitive and innovative advantages, there is a need for them to sustain best practices in promoting a collegial environment among employees to encourage their innovative work behaviours to thrive. Hence, a long-term employee development plan should be crafted by the companies putting emphasis on nurturance of openness, critical thinking, and risk calculation. Secondly, as to managerial implication, there is a need for company managers and supervisors to clearly articulate the directions of their companies by allowing the concept of shared leadership where every employee is given a chance to contribute to speak ideas to the group without fear so that improvement on the processes, systems, and products will be asked. Thirdly, there is a need for the innovation think-tank units of the food manufacturing companies to get new perspectives for innovation. Fourth, companies should intensify the award system where employees who pursue patenting of process or product will be given higher incentive, in such a way, they will be more motivated to work on innovation. Fifth, the strategic and practical needs of the employees must be addressed so that creativity is assured.

\section{Limitations and Future Research Direction}

Having attained the objectives of this study, it also has its number of limitations, which can be based for future studies. First, the study is only limited to a small sampling size of employees from selected food manufacturing industries without considering the sizes and years established of the companies being surveyed, which can be a limiting factor on the test of differences. Second, a simple survey correlational research design was utilized, which limits limited assumptions regarding the data and the variable. A hybrid research design using two or more methods can be more reliable to triangulate the findings gathered. Third, future studies are encouraged whether to replicate or adapt the context of the study to other manufacturing industries to find out the emerging organizational climate and innovative work behaviour of the employees.

\section{Conclusion}

This study adds to the existing body of literature on the organizational climate and employee innovative work behaviour among food manufacturing industries in Malaysia. The study employed a descriptive correlational survey research design to a total sampled 260 employees. Results revealed that a favourable organizational climate on innovation, proactivity, and risk-taking prevails among the companies. Likewise, a very high level of innovative work behaviour is shared among the employees on idea exploration, generation, championing, and implementation. Meanwhile, the test of differences showed that employee unit, years of service, gender, and position spelt significant differences in the perception of the employees on organizational climate and their innovative work behaviour. A significant relationship is found between organizational climate and employee innovative work behaviour, suggesting that for food manufacturing industries to sustain innovative and competitive advantages, there is a need to promote a nurturing and encouraging entrepreneurial organizational climate. Finally, a congruency among the domains of organizational climate and employee innovative work behaviour is found. Theoretical, practical, and limitations of the study for future researchers are discussed.

\section{References}

1. Adams, K. (2006). The sources of innovation and creativity. A paper commissioned by the National Center on Education and the Economy for the New Commission on the Skills of the American Workforce. Washington DC: National Centre on Education and the Economy.

2. Baer, M., \& Frese, M. (2003). Innovation is not enough: Climates for initiative and psychological safety, process innovations, and firm performance. Journal of Organizational Behavior: The International Journal of Industrial, Occupational and Organizational Psychology and Behavior, 24(1), 45-68. 
3. Bagheri, A., \& Akbari, M. (2018). The impact of entrepreneurial leadership on nurses' innovation behavior. Journal of Nursing Scholarship, 50(1), 28-35.

4. Banerjee, P., Gupta, R., \& Bates, R. (2017). Influence of organizational learning culture on knowledge worker's motivation to transfer training: Testing moderating effects of learning transfer climate. Current Psychology, 36(3), 606-617.

5. Bani-Melhem, S., Zeffane, R., \& Albaity, M. (2018). Determinants of employees' innovative behavior. International Journal of Contemporary Hospitality Management, 30(3), 1601-1620.

6. Basadur, M. (2004). Leading others to think innovatively together: Creative leadership. The Leadership Quarterly, 15(1), 103-121.

7. Berthoin Antal, A., Debucquet, G., \& Frémeaux, S. (2017). When top management leadership matters: Insights from artistic interventions. Journal of Management Inquiry, 1056492617726393.

8. Černe, M., Kaše, R., \& Škerlavaj, M. (2016). This idea rocks! Idea championing in teams. In Capitalizing on Creativity at Work. Edward Elgar Publishing.

9. Choudhury, G. (2012). The dynamics of organizational climate: An exploration. Management Insight, 7(2).

10. Covin, J. G., \& Slevin, D. P. (1989). Strategic management of small firms in hostile and benign environments. Strategic Management Journal, 10(1), 75-87.

11. de Jong, J., \& den Hartog, D. (2010). Measuring innovative work behaviour. Creativity and Innovation Management, 19(1), 23-36.

12. De Silva, M., Howells, J., \& Meyer, M. (2018). Innovation intermediaries and collaboration: Knowledge-based practices and internal value creation. Research Policy, 47(1), 70-87.

13. Dengler, C., Schönmann, A., Lohmann, B., \& Reinhart, G. (2017). Cycle-oriented evaluation of production technologies: Extending the model of the production cycle. Procedia CIRP, 61, 493-498.

14. Dewett, T. (2006). Exploring the role of risk in employee creativity. The Journal of Creative Behavior, 40(1), 27-45.

15. Dong, Y., Bartol, K. M., Zhang, Z. X., \& Li, C. (2017). Enhancing employee creativity via individual skill development and team knowledge sharing: Influences of dual-focused transformational leadership. Journal of Organizational Behavior, 38(3), 439-458.

16. Fay, D., Lührmann, H., \& Kohl, C. (2004). Proactive climate in a post-reorganization setting: When staff compensate managers' weakness. European Journal of Work and Organizational Psychology, 13(2), 241-267.

17. García-Granero, A., Llopis, Ó., Fernández-Mesa, A., \& Alegre, J. (2015). Unraveling the link between managerial risk-taking and innovation: The mediating role of a risk-taking climate. Journal of Business Research, 68(5), 1094-1104.

18. Getz, I., \& Robinson, A. G. (2003). Innovate or die: Is that a fact? Creativity and Innovation Management, 12(3), 130-136.

19. Ghosh, K. (2015). Developing organizational creativity and innovation: Toward a model of selfleadership, employee creativity, creativity climate and workplace innovative orientation. Management Research Review, 38(11), 1126-1148.

20. Gitelman, L. D., Gavrilova, T. B., Kozhevnikov, M. V., \& Starikov, E. M. (2019). Ensuring resilience and agility of complex organizational-technical systems. Management and Applications of Complex Systems, 45.

21. Hammond, M. M., Neff, N. L., Farr, J. L., Schwall, A. R., \& Zhao, X. (2011). Predictors of individuallevel innovation at work: A meta-analysis. Psychology of Aesthetics, Creativity, and the Arts, 5(1), 90.

22. Hassan, H., Asif, J., Waqar, N., Khalid, S., \& Abbas, S. (2018). The impact of knowledge sharing on innovative work behavior. Asian Journal of Multidisciplinary Studies, 6(5), 22-25. 
23. Hong, Y., Liao, H., Raub, S., \& Han, J. H. (2016). What it takes to get proactive: An integrative multilevel model of the antecedents of personal initiative. Journal of Applied Psychology, 101(5), 687.

24. Howell, J. M., Shea, C. M., \& Higgins, C. A. (2005) Champions of product innovations: Defining, developing, and validating a measure of champion behavior. Journal of Business Venturing, 20, 64161.

25. Hsu, M. L., \& Chen, F. H. (2017). The cross-level mediating effect of psychological capital on the organizational innovation climate-employee innovative behavior relationship. The Journal of Creative Behavior, 51(2), 128-139.

26. Hu, A. G., Zhang, P., \& Zhao, L. (2017). China as number one? Evidence from China's most recent patenting surge. Journal of Development Economics, 124, 107-119.

27. Hughes, D. J., Lee, A., Tian, A. W., Newman, A., \& Legood, A. (2018). Leadership, creativity, and innovation: A critical review and practical recommendations. The Leadership Quarterly, 29(5), 549569.

28. Hughes, M., \& Morgan, R. E. (2007). Deconstructing the relationship between entrepreneurial orientation and business performance at the embryonic stage of firm growth. Industrial Marketing Management, 36(5), 651-661.

29. Iddris, F., Awuah, G. B., \& Gebrekidans, D. A. (2016). Achieving supply chain agility through innovation capability building. International Journal of Supply Chain and Operations Resilience, 2(2), 114-143.

30. Imran, R., Saeed, T., Anis-Ul-Haq, M., \& Fatima, A. (2010). Organizational climate as a predictor of innovative work behavior. African Journal of Business Management, 4(15), 3337-3343.

31. Jaiswal, N. K., \& Dhar, R. L. (2015). Transformational leadership, innovation climate, creative selfefficacy and employee creativity: A multilevel study. International Journal of Hospitality Management, 51, 30-41.

32. Janssen, O. (2000). Job demands, perceptions of effort-reward fairness and innovative work behaviour. Journal Of Occupational and Organizational Psychology, 73(3), 287-302.

33. Jeanes, E. L. (2006). 'Resisting creativity, creating the new'. A Deleuzian perspective on creativity. Creativity and Innovation Management, 15(2), 127-134.

34. Jin, G., Zhu, Y., \& Xu, Y. (2017). Mystery behind Chinese liquor fermentation. Trends in Food Science \& Technology, 63, 18-28.

35. Joe, T., Bessant, J., \& Pavitt, K. (2005). Managing innovation: Integrating technological, market and organizational change. John Wiley \& Sons.

36. Ju, B. (2012). An evaluation of critical factors influencing product innovation in the food industry A case study of China Mengjiu Dairy Company. International Journal of Business and Management, 7(3), 104.

37. Kang, J. H., Matusik, J. G., Kim, T. Y., \& Phillips, J. M. (2016). Interactive effects of multiple organizational climates on employee innovative behavior in entrepreneurial firms: A cross-level investigation. Journal of Business Venturing, 31(6), 628-642.

38. Kang, J. H., Solomon, G. T., \& Choi, D. Y. (2015). CEOs' leadership styles and managers' innovative behaviour: Investigation of intervening effects in an entrepreneurial context. Journal of Management Studies, 52(4), 531-554.

39. Kang, S., Hao, X., Du, T., Tong, L., Su, X., Lu, H., ... \& Ding, R. (2017). Improving agricultural water productivity to ensure food security in China under changing environment: From research to practice. Agricultural Water Management, 179, 5-17.

40. Khalili, A. (2016). Linking transformational leadership, creativity, innovation, and innovationsupportive climate. Management Decision, 54(9), 2277-2293. 
41. Kleysen, R. F., \& Street, C. T. (2001). Toward a multi-dimensional measure of individual innovative behavior. Journal of intellectual Capital, 2(3), 284-296.

42. Li, C., Zhao, H., \& Begley, T. M. (2015). Transformational leadership dimensions and employee creativity in China: A cross-level analysis. Journal of Business Research, 68(6), 1149-1156.

43.Li, M., Liu, Y., Liu, L., \& Wang, Z. (2017). Proactive personality and innovative work behavior: The mediating effects of affective states and creative self-efficacy in teachers. Current Psychology, 36(4), 697-706.

44. Li, V., Mitchell, R., \& Boyle, B. (2016). The divergent effects of transformational leadership on individual and team innovation. Group \& Organization Management, 41(1), 66-97.

45. Li, W., Bhutto, T. A., Nasiri, A. R., Shaikh, H. A., \& Samo, F. A. (2018). Organizational innovation: The role of leadership and organizational culture. International Journal of Public Leadership, 14(1), 3347.

46. Lin, H. C., \& Lin, P. C. (2019). The interplay between CEO-TMT exchange level and differentiation: Implications for firm competitive behaviors and performance. Journal of Business Research, 95, 171-181.

47. Liu, F., Chow, I. H. S., Zhang, J. C., \& Huang, M. (2019). Organizational innovation climate and individual innovative behavior: Exploring the moderating effects of psychological ownership and psychological empowerment. Review of Managerial Science, 13(4), 771-789.

48. Liu, Z., Ge, L., \& Peng, W. (2016). How organizational tenure affects innovative behavior? The role of culture difference and status determinants. Nankai Business Review International, 7(1), 99-126.

49.Lopez, K. R. B., Gaticales, N. P., Provido, A. V. C., Santelices, S. M. B., \& Arcinas, M. M. (2021). Social Contagion of Astrology in the Social Media amid COVID-19 Pandemic. International Journal of Multidisciplinary: Applied Business and Education Research, 2(4), 349-363.

50. Lu, Y., Jenkins, A., Ferrier, R. C., Bailey, M., Gordon, I. J., Song, S., ... \& Zhang, Z. (2015). Addressing China's grand challenge of achieving food security while ensuring environmental sustainability. Science Advances, 1(1), e1400039.

51. MacCormick, J. S., \& Parker, S. K. (2010). A multiple climates approach to understanding business unit effectiveness. Human Relations, 63, 1771-1806.

52. Madjar, N., Greenberg, E., \& Chen, Z. (2011). Factors for radical creativity, incremental creativity, and routine, noncreative performance. Journal of Applied Psychology, 96(4), 730.

53. Magulod Jr, G. C. (2017). Factors of school effectiveness and performance of selected public and private elementary schools: implications on educational planning in the Philippines. Asia Pacific Journal of Multidisciplinary Research, 5(1), 73-83.

54. Malerba, F. (2007). Innovation and the evolution of industries. In Innovation, Industrial Dynamics and Structural Transformation (pp. 7-27). Springer, Berlin, Heidelberg.

55. Martín-de Castro, G. (2015). Knowledge management and innovation in knowledge-based and high-tech industrial markets: The role of openness and absorptive capacity. Industrial Marketing Management, 47, 143-146.

56. McAdam, R., \& McClelland, J. (2002). Individual and team-based idea generation within innovation management: Organisational and research agendas. European Journal of Innovation Management, $5(2), 86-97$.

57. Mehmood, M. S., Jian, Z., Waheed, A., Younas, A., \& Khan, S. Z. (2019). Impact of Entrepreneurial Leadership on Employee's Innovative Behavior: Mediating role of Psychological Empowerment. In Proceedings of the 2019 3rd International Conference on Management Engineering, Software Engineering and Service Sciences (pp. 223-229). ACM.

58. Miao, J., Liang, Y., Chen, L., Wang, W., Wang, J., Li, B., ... \& Xu, Z. (2017). Formation and development of Staphylococcus biofilm: with focus on food safety. Journal of Food Safety, 37(4), e12358. 
59. Ming, T., Yang, Z., \& Zhen, T. (2016). Research on the relationship between innovation and growth of food manufactures in developing country: Evidence from the listed company in China. Advance Journal of Food Science and Technology, 10(6), 460-464.

60. Montani, F., Courcy, F., \& Vandenberghe, C. (2017). Innovating under stress: The role of commitment and leader-member exchange. Journal of Business Research, 77, 1-13.

61. Naranjo-Valencia, J. C., Jiménez-Jiménez, D., \& Sanz-Valle, R. (2016). Studying the links between organizational culture, innovation, and performance in Spanish companies. Revista Latinoamericana de Psicología, 48(1), 30-41.

62. Natalicchio, A., Ardito, L., Savino, T., \& Albino, V. (2017). Managing knowledge assets for open innovation: A systematic literature review. Journal of Knowledge Management, 21(6), 1362-1383.

63. Nencini, A., Romaioli, D., \& Meneghini, A. M. (2016). Volunteer motivation and organizational climate: Factors that promote satisfaction and sustained volunteerism in NPOs. VOLUNTAS: International Journal of Voluntary and Nonprofit Organizations, 27(2), 618-639.

64. Newman, A., Herman, H. M., Schwarz, G., \& Nielsen, I. (2018). The effects of employees' creative self-efficacy on innovative behavior: The role of entrepreneurial leadership. Journal of Business Research, 89, 1-9.

65. Ng, T. W., \& Feldman, D. C. (2013). A meta-analysis of the relationships of age and tenure with innovation-related behaviour. Journal of Occupational and Organizational Psychology, 86(4), 585616.

66. Norton, T. A., Zacher, H., \& Ashkanasy, N. M. (2015). Pro-environmental organizational culture and climate. In J. L. Robertson, \& J. Barling (Eds.), The psychology of green organizations (pp. 322-348). Oxford University Press.

67. Orth, M., \& Volmer, J. (2017). Daily within-person effects of job autonomy and work engagement on innovative behaviour: The cross-level moderating role of creative self-efficacy. European Journal of Work and Organizational Psychology, 26(4), 601-612.

68.Pati, A. (2019). The influence of leadership and organizational culture on employee work satisfaction in Bolmut Regency. Asia Pacific Journal of Management and Education, 2(2), 106-112.

69. Patterson, M. G., West, M. A., Shackleton, V. J., Dawson, J. F., Lawthom, R., Maitlis, S., ... \& Wallace, A. M. (2005). Validating the organizational climate measure: Links to managerial practices, productivity and innovation. Journal of Organizational Behavior, 26(4), 379-408.

70. Perry-Smith, J. E., \& Mannucci, P. V. (2017). From creativity to innovation: The social network drivers of the four phases of the idea journey. Academy of Management Review, 42(1), 53-79.

71. Petrou, P., Bakker, A. B., \& Bezemer, K. (2019). Creativity under task conflict: The role of proactively increasing job resources. Journal of Occupational and Organizational Psychology, 92(2), 305-329.

72.Puspitawati, N. M. D., \& Atmaja, N. P. C. D. (2019). The role of organizational commitment mediating organizational climate with turnover intention. International Journal of Applied Business and International Management, 4(3), 23-32.

73.Rong, Z., Wu, X., \& Boeing, P. (2017). The effect of institutional ownership on firm innovation: Evidence from Chinese listed firms. Research Policy, 46(9), 1533-1551.

74. Rowley, J., Baregheh, A., \& Sambrook, S. (2011). Towards an innovation-type mapping tool. Management Decision, 49(1), 73-86.

75. Saraswati, N. P. A. S., \& Putra, G. B. B. (2020). Competency and creativity as a relationship that interpretes between the perception of an organizational support on performance of the craftsman of Ikat Endek in Klungkung Bali. Asia Pacific Journal of Management and Education, 3(1), 1-11.

76. Sauid, M. K., Kamarudzaman, K., Ebrahim, Z. B., Mustakim, N. A., \& Mokhtar, N. (2018). The relationship between self-leadership skills and employee innovative work behavior (IWB). Gading Journal for the Social Sciences, 21(02), 19-26. 
77. Scott, S. G., \& Bruce, R. A. (1994). Determinants of innovative behavior: A path model of individual innovation in the workplace. Academy of Management Journal, 37(3), 580-607.

78. Sethibe, T., \& Steyn, R. (2016). Organizational climate, innovation and performance: A systematic review. Journal of Entrepreneurship and Innovation in Emerging Economies, 2(2), 161-174.

79. Shahzad, F., Xiu, G., \& Shahbaz, M. (2017). Organizational culture and innovation performance in Pakistan's software industry. Technology in Society, 51, 66-73.

80. Shanker, R., Bhanugopan, R., van der Heijden, B. I. J. M., \& Farrell, M. (2017). Organizational climate for innovation and organizational performance: The mediating effect of innovative work behavior. Journal of Vocational Behavior, 100, 67-77.

81. Spitzmuller, M., Sin, H. P., Howe, M., \& Fatimah, S. (2015). Investigating the uniqueness and usefulness of proactive personality in organizational research: A meta-analytic review. Human Performance, 28(4), 351-379.

82. Sternberg, R. J., \& Lubart, T. I. (1991). An investment theory of creativity and its development. Human Development, 34(1), 1-31.

83. Vong, L. T. N., Ngan, H. F. B., \& Lo, P. C. P. (2018). Does organizational climate moderate the relationship between job stress and intent to stay? Evidence from Macau SAR, China. Journal of Chinese Human Resource Management, 9(1), 2-20.

84. Wallace, J. C., Edwards, B. D., Paul, J., Burke, M., Christian, M., \& Eissa, G. (2016). Change the referent? A meta-analytic investigation of direct and referent-shift consensus models for organizational climate. Journal of Management, 42(4), 838-861.

85. Wang, H., \& Chang, Y. (2017). The influence of organizational creative climate and work motivation on employee's creative behavior. Journal of Management, 3, 6 .

86. Wang, X. H. F., Kim, T. Y., \& Lee, D. R. (2016). Cognitive diversity and team creativity: Effects of team intrinsic motivation and transformational leadership. Journal of Business Research, 69(9), 3231-3239.

87. Wei, S. J., Xie, Z., \& Zhang, X. (2017). From "Made in China" to "Innovated in China": Necessity, prospect, and challenges. Journal of Economic Perspectives, 31(1), 49-70.

88. Woodman, R. W., Sawyer, J. E., \& Griffin, R. W. (1993). Toward a theory of organizational creativity. Academy of Management Review, 18(2), 293-321.

89. Woods, S. A., Mustafa, M. J., Anderson, N., \& Sayer, B. (2018). Innovative work behavior and personality traits: Examining the moderating effects of organizational tenure. Journal of Managerial Psychology, 33(1), 29-42.

90. Wu, C. M., \& Chen, T. J. (2018). Collective psychological capital: Linking shared leadership, organizational commitment, and creativity. International Journal of Hospitality Management, 74, 75-84.

91. Xie, Z., \& Zhang, X. (2015). The patterns of patents in China. China Economic Journal, 8(2), 122-142. 